\title{
A SECOND NOTE ON "MACRODONTISM" OF THE
}

\section{MELANESIANS. (1)}

\author{
By N. de Miklouho-Maclay.
}

\section{(Plate XLIX.)}

In the resumé of the results of Anthropological Observations during a trip to Melanesia in 1879-80, (2) I have stated inter alia, that I had the opportunity of making further observations re "Macrodontism" in the Admiralty Islandsand the Lub Archipelago.

When Ifirst (in 1876) discovered thispeculiarity at the Admiralty Islands, the natives, who had been before then very little in contact with white men, were exceedingly shy, and it was only a chance and a matter of some tact and great patience to induce the natives to let me examine, measure, and sketch their teeth. A closer inspection was completely out of question, they would resist or run away at once. It was therefore not easy to come to a decided opinion about the nature of the enlargement of the teeth.

At the Islands of Lub, I succeeded at last in obtaining a piece of an enlarged tooth, the microscopical and chemical examination of which might decide the question of the nature of "Macrodontism." For various reasons, I decided to send the above-mentioned specimen to Prof. Virchow at Berlin, but, to my greatestannoyance, the small parcel given in charge of a gentleman going from Sydney to Europe, was lost by his carelessness (was forgotten in the cabin, when changing the steamer at Point de Galle). I was informed about the loss of this interesting specimen only on my return from the cruise amongst the Islands of Melanesia (1879 and 1880),

(1) My first note "On Macrodontism," appeared in the Proceed. of the Linn. Soc. of N.S.W., Vol. III., p. 169.

(2) A resumé of the results of Anthropological and Anatomical Researches in Melanesia and Australia (March 1879 January 1881) in the Proceed. of the Linn. Soc. of N.S.W., Vol. VI., p. 171. 
during which, as already mentioned, I succeeded in making further investigation on "Macrodontism."

As it was now my third visit to these Islands (Admiralty and Lub Islands), the natives treated me as an old acquaintance, especially as I could speak a little of their dialect. Living on shore, my face, manners and ways became quite familiar to the natives, who remembered my two former visits very well. Finding by experience that my proceedings (anthropological measurements, sketching, photographing, etc., etc.), were quite harmless, the natives began to regard them with much less distrust and antipathy than before, and many large-toothed people had their teeth examined, measured, and sketched without making any objection. This time I examined a greater variety of the large teeth and succeeded in gecting some pieces of the same, and soon arrived at a different opinion to my former one (1), namely, that the enlargement of the teeth is due not to a real enlargement of the tooth (an hypertrophy of the dentinum), but is simply an excessive accumulation of tartar, the formation of which is increased by the constant supply of lime from the chewing of the areca-betel-lime combination (2). The examination of a large tooth, which I purchased, left no doubt that the same was covered with a kind of biack, hard incrustation, which could be gradually removed with a sharp scalpel in the shape of more or less thin layers, leaving the apparently unaltered tooth in the centre. In another specimen, the tooth could be removed like a kernel from a nutshell.

I showed one of the specimens of the enlarged teath to Mr. P. R. Pedley, who expressed his conviction that the dark brown crust on the teeth could not be anything else, but a salivary calculus, peculiarly stained by the special food of the natives.

(1) Loc. cit. Proceed. Linn. Soc. of N.S.W., Vol. 1, p. 172.

(2) The root of the Piper betel is used by the natives of Admiralty Islands to a greater extent than in other places, where the leaves and fruits are mostly in demand. The proportion of different ingredients used by arecabetel-lime-chewers, appeared to me very different in different countries, which differences in the combination of course alters the immediate effect of the chewing, and producesin time different results on the bodies of the indulgers. Moreover, in some places (for instance, the Malay-Peninsula and some Islands of the Malay Archipelago) Tobacco and Gambier (Nauclea gambir) are added to the Areca nut and the Betel. 
Some months after my return to Sydney (in January, 1881), I received from Berlin the "Sitzungsberichte der Berliner Gesellschaft für Anthropologie, Ethnologie und Urgeschichte," for 1881, in which a letter appeared from F. A. de Roepstorff, Government Resident on the Nicobar Islands (1). The subject of the letter is: the remarkably large teeth of the Nicobarese. In this letter the writer says, that having read my account about the large-toothed Melanesians, (2) and examined the adjoined plate (3), he was surprised to find that amongst the Nicobar Islanders this peculiarity is also not a rare occurrence. Mr. Roepstorff forwarded to Prof. Virchow some large teeth, which he acquired from the tribe of the Shom-Moat of the Nancowry Group. The chemical analysis proved that the incrustation which covered the teeth of these men was a kind of tartar (Zahnconcrement) consisting chiefly of brown-stained lime. (4) Prof. Virchow referring to this

(1) Sitzungsberichte der Berliner Gesellschaft für Anthropologie, Ethnologie und Urgeschichte. Sitzung am 18 Juni, 1881, p. 218.

(2) Loc. cit. Sitzung am 16 Dec., 1876.

(3) Loc. cit. Plate XXVI.

(4) Die von Herm Salkowski angestellte chemische Analyse ergab folgendes Resultat :-

"Die feingepulverte Substanz schwärzt sich beim erhitzen unter Verbrei" tung des Geruches nach verbranntem Horn, sie löst sich sowohl vor, wie "nach dem Glühen unter Hinterlassung eines unbedeutenden Rüickstands " und unter Aufbrausen (Kohlensäure) in Salzsäure. Die Salzsäure

“ Lösung enthält als Hauptbestandtheile Kalk und Phosphorsäure, daneben

“Magnesia, Eisenoxyd, sehr geringe Mengen von Alkalien, Spuren von

“Schwefelsäure und Kieselsäure. Die Salpetersäure Lösung giebt mit

"Silberlösung keine merkliche Trübung, its also frei von Chloriden resp.

"Salzsäure."

Die quantitave Bestimmung der Hauptbestandtheile ergab folgende Zusammensetzung:

\begin{tabular}{|c|c|c|}
\hline Wasser .................. & $5 \cdot 95$ & et. \\
\hline 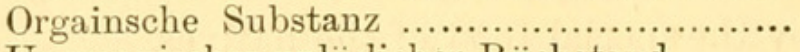 & $9 \cdot 10$ & , \\
\hline 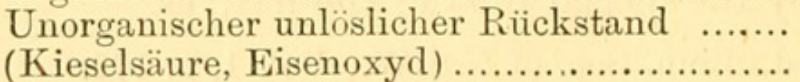 & 0.87 & \\
\hline 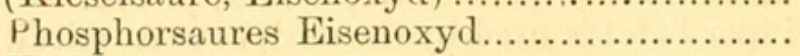 & $2 \cdot 26$ & \\
\hline Kalk ….................................. & $45 \cdot 24$ & \\
\hline Magnesia ............................. & 0.68 & \\
\hline Phorphorsäure …............................... & $30 \cdot 73$ & \\
\hline 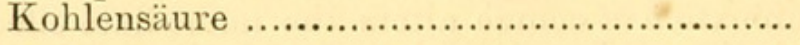 & $4 \cdot 87$ & \\
\hline
\end{tabular}

$99 \cdot 70$ p. ct.

(Verhandlungen der Berliner Gesellschaft für Anthropologie, Ethnologie und Urgeschichte, Jahrgang, 1881. Sitzung von 18 Juni, p. 219.) 
communication of Mr. Roepstorff made the remark (1), that although the large size of the teeth of the Nicobarese depends, according to the chemical analysis, upon the formation of a new kind of tartar (Weinstein), it remains still a question, whether it is possible to explain in the same way the large teeth of the Melanesians described by me, and that in the latter case further clearing up is necessary.

The present note shows, that in my opinion, the enlargement of the teeth of the natives of the Admiralty and Lub-Islands is of a similar nature to that which occurs amongst the Nicobar Islanders, and is very likely produced by the same cause. A striking example of the size attained by teeth, incrusted with this kind of tartar, is represented on the adjoined plate. (Figs. 9, 10, 11, 12.)

The very remarkable size of the two lower incisors (carefully measured) causes one to wonder, how they can find room in the mouth.

The "Lechen-tshuven" (2) are regarded by the natives, as far as I could observe, as a kind of beauty, and possessors of such are apparently very proud of them and treat them with care. (3)

The above explains sufficiently why the designation "Macrodontism," must be dropped. It may be replaced by the name Odontolithiasis, which is certainly a more suitable one. (4)

(1) Loc. cit. Sitzung am 18 Juni, 1881, p. 219.

(2) The natives on the Island Sorry' (or Wild Islands) in Nares Harbour, call the large teeth "Lechen-tshuven." Very likely the name in the other dialects of the Admiralty Islands for the same will be different.

(3) Care is necessary, because the enormous teeth have not correspondingly enormous fangs.

(4) I am indebted to Prof. W. J. Stephens for the suggestion of this very appropriate name, from ődovs tooth, and $\lambda_{\iota} \theta i a \sigma \iota s$, stony deposit. 


\section{EXPLANATION OF PLATE XLIX.}

(All the figures, with exception of Fig. 9 and Fig. 10, of natural size.)

Fig. 1-Fig. 4.-Crust of tartar of two upper incisors. The external surfaces dark brown, smooth as if polished.

Fig. 1. - The same from the front.

Fig, 2.-The same from behind.

Fig. 3. - The same from the side.

Fig. 4. - The same from above, showing distinctly that the crust has been covering two incisors.

Fig. 5, Fig. 8.-One of the upper incisors, covered with a dark brown crust of tartar, leaving only a portion of the fang $(f)$ free.

Fig. 5.-The same from the front.

Fig. 6. - The same from behind.

Fig. 7.-The same from the side.

Fig. 8.-The same from below, showing two smooth surfaces.

Fig. 9.-Half-opened mouth in profile of Burumo, a native of the Island Sorry' in Nares Harbour, showing very large salivary calculi covering the incisors. (About one-half of the natural size.)

Fig. 10.-Mouth of the same, en face.

Fig. 11.-Upper surface of the crust of tartar, enclosing the middle incisors of the upper jaw. Exact measures in millimeters.

Fig. 12. Upper surface of the crust of tartar covering the lower incisors. The exact measures are marked in millimeters. The thickness of the larger calculus was exactly $8 \mathrm{~mm}$. The upper outlines of the teeth were covered with detritus of food, Leptothrix buccalis. \&c. 


\section{$2 \mathrm{BHL}$ Biodiversity Heritage Library}

Miklouho-Maclay, N De. 1886. "A second note on "macrodontism" of the Melanesians." Proceedings of the Linnean Society of New South Wales 10, 682-686. https://doi.org/10.5962/bhl.part.17953.

View This Item Online: https://www.biodiversitylibrary.org/item/30482

DOI: https://doi.org/10.5962/bhl.part.17953

Permalink: https://www.biodiversitylibrary.org/partpdf/17953

\section{Holding Institution}

MBLWHOI Library

\section{Sponsored by}

MBLWHOI Library

\section{Copyright \& Reuse}

Copyright Status: NOT_IN_COPYRIGHT

This document was created from content at the Biodiversity Heritage Library, the world's largest open access digital library for biodiversity literature and archives. Visit BHL at https://www.biodiversitylibrary.org. 